\title{
Qadar in Classical and Modern Islamic Discourses: Commending a Futuristic Perspective
}

\author{
WAN FARIZA ALYATI WAN ZAKARIA ${ }^{1}$
}

\begin{abstract}
In classical Islamic era, the discussion on the concept of fate (divine predestination) or qadar has created various debates with regard to its relationship to the problem of freedom (hurriya), choice (ikhtiyar) and free will (irada). The word qadar has been treated differently by various Islamic thinkers such as the jurists, the Sufis, the philosophers and the theologians (mutakkalimun) according to their respective concern. Classical discourse on qadar is found predominantly in debates between two main sects, the Murji'ites and the Jabarites who believe that God had predetermined the human life at one hand, and the others, the Muktazilites and the Qadarites who believe in human's free will. The modern discourse on qadar shifts to different tunes. It is believed that qadar was responsible for paralyzing the energies of the Muslims and was the chief cause of their moral degeneration. The doctrine of qadar causes the Muslims to regard all their actions and achievements as dependent on the will of God and, for the same reason, they were unable to safeguard their rights and protect their countries from tyranny - thus obstructing their overall progress. This paper attempts at discussing both the classical and modern Islamic conceptions of qadar and its dynamism as the source of strength for Muslims to think about the future in positive attitude - that it is the only space which they could actively participate and operate in order to choose their destiny, be it good or bad, whether on the earth as God's servants and vicegerents, as well as in the hereafter where they will taste the consequences of their actions. Understanding the true concept of qadar and also its dynamic association with the organic concept of time is about knowing the consequences of human actions and this is the very basic of futures thinking in Muslim mind.
\end{abstract}

Keywords: Islamic theology, free will, future, predestination, Qadar

In classical Islam - covering six centuries of the Islamic era; i.e., from the year 101 to the year 700 after the Hijrah of the Prophet, the question of time has been discussed within the influence of Greek philosophy. Hence, the philosophical views of time are found in response to, or in agreement with the Greek's philosophical argument on the nature of time. In the ancient Greek, time is regarded as eternal therefore the notion of the eternity of time has created controversy and Muslim philosophers as well as theologians have different views over the issue. In general, the Muslim intellectuals' response can be divided into three categories; the first is those who agree with the eternity of time and the world; the second is those who reject the eternity of time and believes in creation ex nihilo; and the third is those who attempt at reconciliation between the two camps. The first group is best exemplified by the views of Ibn Sina, Ibn Bajjah and to

\footnotetext{
${ }^{1}$ Wan Fariza Alyati Wan Zakaria, Ph.D., Senior Lecturer, Dept. of Theology and Philosophy, Universiti Kebangsaan Malaysia, 43600 BANGI, Selangor, Malaysia, email: aufaa@ukm.edu.my.
} 
some extent, Muhammad ibn Zakariya al-Razi; the second by al-Ghazali and the third by Ibn Rushd. The modern discourse on time, on the other hand, shows a different course diverted from the classical views. But what bind both the classical and the modern alike is the relationship between the understanding of time with the human destiny or qadar.

\section{The Terminology of $a l-Q a d r$}

The word al-qadar derives from word 'qadr' means amount, quantity, magnitude, size, volume, propotion, deal, number, measure (Ba albaki 1995). According to Saleh as-Saleh, the linguistic and Islamic meanings of al-qada' and al-qadar are connected to each other. He elaborates that linguistically, the meaning of al-qada' refers to the: ". . perfect commanding, decreeing, ruling, accomplishing and perfect precision in execution", while al-qadar refers to the: ". . . setting, commanding, executing, and encompassing in due and precise propotions" (Abdul Rahman ibn Saleh al-Mahmud cited in As-Saleh, Saleh S. 1995). In the Quran, we read: "We have indeed revealed This (Message) in the Night of Power: and what will explain to thee what the Night of Power is? The Night of Power is better than a thousand months. Therein come down the angels and the spirit by Allah's permission, on every errand: Peace! This until the rise of the Morn!" (al-Qadr 97:1-5). According to Abdullah Yusuf Ali's translation, the meaning of al-qadar in these suras is power, and laylatu al-qadar refers to the Night of Power. In the Introduction to Translation of Sahih Muslim, the translator, Abdul Hamid Siddiqui says that the word Taqdir used in the Quran does not always signify something predestined. It at times implies a measure or the latent potentialities or possibilities with which Allah created man and all things of Nature. For example: He created everything for its Destiny (or its Measure) (xxv. 2). In Sura 54, verse 9 (the words are): We created everything according to a Measure or Destiny. In both these verses Destiny implies the inward reach of things, their latent potentialities or possibilities.

\section{Classical Discourse on al-Qadr}

Montgomery Watt in his book Islamic Philosophy and Theology: An Extended Survey perceives the pagan Arabs or the pre-Islamic Arab's outlook on dahr as 'fatalism'. The fatalistic view on life lies in the pagan Arabs belief that their successes and misfortunes in life were controlled by Time (dahr). Time therefore is conceived as an impersonal force identified with 'fate' or 'destiny'. Unlike Abdullah who sees this pre-Islamic belief as some sort of deification, Watt views the pagan Arabs belief in Time is not as something to be worshipped, but rather, 'a natural phenomenon which one must accept' (Watt 1985). For Watt, in the pagan Arabs perception, there is a limitation in Time's control over human life for it only fixes the final outcome of his endeavour - particularly his 'term,' (ajal i.e the date of his death), his fortune and provision (rizq) - but not his every act. Fatalism of this kind, he asserts: “. . . was appropriate to the life of the nomads in the deserts and steppes of Arabia... [in bringing] the best hope of making success of one's life in the harsh conditions of the desert" (Watt 1985).

With the coming of Islam, the Quran's message on tawhid had transformed the thought of the Arabs in which God has become the sole source of control of human life. This, according to Watt, refers to the verse answering the previous one: "It is Allah Who gives you life, then gives you death; then He will gather you for together for the Day of Judgement about which there is no doubt": but most men does not understand (Al-Quran 45:26). Here, Watt (1985) concludes that Time has been replaced by God as the source of misfortune, as the Quran says: "No misfortune can happen on earth or in your souls but is recorded in a decree before We bring it into existence: that is truly easy for Allah" (Al-Quran 57:22). Watt in his analysis has implied the influence of pre-Islamic fatalist view on the Muslims view regarding the concept of predestination (qadar). 
In classical Islamic era, the discussion on the concept of fate (divine predestination) or qadar has created various debates with regard to its relationship with the problem of freedom (hurriya), choice (ikhtiyar) and free will (irada). According to Leaman, the term qadar which means the measuring out or divine determination is used interchangeably with qudra which means ability or power. In the Quran, qadar also implies God's power and knowledge (Al-Quran 2: 256; 54: 49; 15: 21). Seyyed Hossein Nasr in this regard, emphasizes that the word qadar has been treated differently by various Islamic thinkers such as the jurists, the Sufis, the philosophers and the theologians (mutakkalimun) according to their respective concern. The jurists when discussing on qadar, are more "... concern with the rights and liberty that are the outcome of conformity to the divine law (sharia); sufis seek inner freedom through liberation from man's bondage to the lower self; philosophers generally assert the reality of human free will from the standpoint of al-Farabi's (d.970) political philosophy; and the theologians (mutakallimun) are mainly concerned with the relationship between the divine will and human will, and how the former limits the latter" (Nasr 1996).

Predominantly, classical discourse on qadar is found in debates between two main sects, the Murji'ites and the Jabarites who believe that God had predetermined the human life at one hand, and the other, the Muktazilites and the Qadarites who believe in human's free will. The Murji'ites and the Jabarites found support for their views in the Quran. However, as we have discussed in the previous section on the Quranic conception of time, these verses can be misunderstood to conform the pre-Islamic Arabs outlook of fatalism. In this regard, Watt views that it can therefore be said that the pre-Islamic Arabs had influenced the mainstream Islam in giving the role of Time (dahr) or fate as the controller of human life to God (Watt 1994).

\section{Modern Discourse on al-Qadr}

The modern discourse on qadar shifts to different tunes. It is believed that qadar was responsible for paralyzing the energies of the Muslims and was the chief cause of their moral degeneration. The doctrine of qadar causes the Muslims to regard all their actions and achievements as dependent on the will of God and, for the same reason, they were unable to safeguard their rights and protect their countries from tyranny -thus obstructing their overall progress (Moazzam 1984). According to Moazzam Anwar, Jamal al-Din al-Afghani set aside this criticism and held that it confused the doctrine of qadar with that of jabr. Explaining the difference between the two, he claimed that Afghani condemned the doctrine of jabr as the deterministic view which reduced man merely to an inanimate being, having no will of his own and no power over his actions. Moazzam says that Afghani also condemned the attitude presenting God as a coercive power upon whose will the existence of each and every event depended and which deprived man the right of choice (ikhtiyar) in his actions and thus rendered futile human faculties of thought and action. Such an attitude would rob man of all urges for positive struggle, learning and acquisition, and would make his life useless (Moazzam 1984).

In explaining the close relationship between nature and human will, Afghani believes that human will is produced by perception (idrak) of the external phenomena and it is, in fact, one of the links in the chain of causes. The source of the causes underlying external events is God, who has subordinated each event to a like cause. Thus Afghani accepts God's power over human will, not directly but through the law of causation. In his further analysis on Afghani's concept on the relationship between kasb (acquisition) and ikhtiyar with the notion and freedom and God's power, Moazzam (1984) writes: “. . This situation leads to the question of human responsibility and brings in the issues of kasb (acquisition) and ikhtiyar (choice). Without making any distinction between the two terms and using both of them in the sense of ikhtiyar, he 
asserts that God has endowed man with full powers of choice over his actions. It is only the right of choice which makes human responsibility just and valid, and as such, man stands responsible to the laws of Shariah for his acts and is liable to reward and punishment".

Thus, Moazzam (1984) concludes that Afghani: ". . . maintains that strong faith in law having full power over the events gives strength to human conduct. Belief in al-qada wa al-qadar makes man brave, patient, bold, generous and self-sacrificing so that he is prepared to face the circumstances without fear. Again, belief in predetermined death, faith in God as the provider of one's livelihood, and complete trust in an Omnipotent Being gives sufficient courage to fight in defence of truth. He points out that it was in this sense that early Muslims which were brought about, according to him, by a religious momentum generated mostly by this belief. Besides, this belief does not rest exclusively on religious sanction as such. It is more a rational attitude than a theological dogma. The rule of this law prevailed over all great human achievements wherever they took place". Afghani's understanding and treatment on qadar is thus not a fatalistic stance but a positivistic one.

Conclusively, the negative perception of the concept of al-qada' and al-qadar or taqdir, as demonstrated by Moazzam's analysis on Afghani, and also others clearly shows its frailty. Hence, as Al-Anani asserts that: ". . . it is only fair that Muslims face the cause and effect relationship between their behavior and their condition. Ignorance of this relationship is bound to harm the cause of da wah and of Islam. Many Muslims feel that their tragic situation today results from the religion itself. Those who are ignorant of Islam feel that Islamic teachings have something in them that has caused their backwardness. They believe that Islam teaches a kind of fatalism incompatible with the responsible attitude needed to subjugate the forces of the universe and thereby keep pace with modern times and with the demands of modern civilization. Though this concept is totally opposed to Islamic teachings, the material success achieved by Western countries deepened their doubts about Islam and caused them to accuse it of passivity and backwardness" (al-Anani 1990).

As a matter of fact, the dynamic belief and concept of al-qada' and al-qadar is the source of strength for Muslims must think about the future in positive-minded attitude - that it is the only space which they could actively participate and operate in order to choose their destiny, be it good or bad, whether on the earth as God's servants and vicegerents, as well as in the hereafter where they will taste the consequences of their actions. Understanding the concept of al-qada' and al-qadar and also its dynamic association with the organic concept of time is about knowing the consequences of human actions and this is the very basic of futures thinking in Muslim mind. This is supposed to change and uplift their mind and spirit in order to revive their understanding of their own religion, and hence to resolve their present malaise, as the Quran says: "Verily, never will God change the condition of a people until they change their inner selves" (Al-Quran 13:11).

Another response for the modern discourse on qadar is the response of the salaf as found in the work of Saleh As-Saleh in Fate in Islam: The Salaf's guide to the understanding of alQada' wa al-Qadar. As-Saleh relates his discussion on qadar with another term qada'. The Islamic meaning of al-qadar according to him: ". . . is the ability of Allah: where He knew, wrote, willed, and created all things in due propotion before and according to a precise measure" (Ahmad ibn Hanbal in As-Saleh 1995) and this knowledge encompasses all things even before they exist and all of them have been written in a Book called al-Lauh al-Mahfuz (The Preserved Tablet) due to their predestined propotions and specific measures. On the other hand, al-qada' according to him: ". . . is the perfectly precise execution and accomplishment of all things predestined to occur exactly in accordance with God's previous Knowledge, Writing, and Will" (AsSaleh 1995). Based on both meanings, the strong relationship between both words is obviously shown in which their meanings can be used interchangeably when separated, but differ when 
stated together. He also gives an example of how the usage of both words connote different meanings, such as: ". . . when it is generalized, al-qadar encompasses al-qada' and vice versa. But when it is said, al-qada' and al-qadar, then al-qadar means the predestination of things, and when the predestined matter occurs, it is then called al-qada" (As-Saleh 1995).

As-Saleh stresses that we must understand the nature of the actions of Allah (afal Allah) and the actions of man ( $a f^{\prime}$ 'al al-'ibad). These two realms of actions denote the realm of God's power/ability as well as the realm of man's power/ability and thus, must be understood correctly, as the source of man's actions is actually Allah Himself for He is the Sole Creator of everything, including man's deeds. This fact refers to the Quranic verse: "Verily! Allah is the Creator of everything, and He is the Wakil (Guardian, Disposer of affairs, Trustee) over all things" (39:62). In another verse, it says: "That is Allah, your Rabb, the Creator of everything" (40:62) and: "Say (O Muhammad) that Allah is the Creator of everything, and He is the One, the Irresistable" (13:16). As-Saleh's explanation regarding the nature of these two realms needs further attention as he says:

The rank of al-Khalq (the Creation) includes the Actions of Allah and the actions of His creatures. The Actions of Allah are true and real. They conform to what is entailed by His Names and Attributes. They influence all of creation in accordance with His Knowledge, Mashee'ah [Will], and Ability. Nothing moves, no matter how small it is, except by His Mashee'ah, Knowledge, and Ability...In all of His actions there is perfect wisdom. He does not do anything in vain nor His action devoid of any meaning. His Actions are Real, AllWise, and All-Just. His creatures, and their deeds, are His creation. The slave of God has real ability, will, choice and action. Man's ability to move and to believe is actions that are truly attributed to him. These actions are created by Allah. Man's movement, standing, sitting, etc are real actions which Allah decreed, set under His ability, willed, and created them for him. Man's will and actions are next to His (As-Saleh 1995).

Al-Qadar connotes a limitation as well as ability. In this sense, every living creature has its own measure, limit, ability and due proportion and working within this system signifies God's Intelligent and His perfect wisdom for He has created the universe with distinctive characteristics which operates under particular law of order. This is the scientific aspect of the concept of al-qadar whereby it works compatibly with God's law of order (Sunnatullah). Therefore, the whole concept of al-qada' and al-qadar should be understood in a bigger picture or framework - to understand the nature of God's law of order or system that has been preordained to all of His creations. In fact nothing in this systematic world of God can be operated without specific understanding of the methods of their operations. With this in mind, it is impossible to correlate the cause of the backwardness of Muslims with the belief in al-qada' and al-qadar except that Muslims themselves have unconsciously misunderstood the true meaning of both concepts. The belief in al-qada' and al-qadar should therefore be understood as a source of strength that God has given to every human being his own capacity and ability to work and act, and this is the basic rights of freedom and at the same time a responsibility, for he can choose the course of his life whether it is good or bad and thus, will be judged through his actions ( $\mathrm{amal}$ ) and intentions (niyyah). This is the justice of God.

At this point, we could raise a question as to what then is the stand of human beings in dealing with al-qadar? As-Saleh's explanation in this matter would shed light in understanding how human being should act and react when dealing with this situation:

The slave's stand towards al-Qadar has two levels: (1) before the taqdir takes place: he should seek the help from God, depend upon Him, and supplicate Him; (2) after the taqdir takes place: If the taqdir is different from what he had worked for (lawful and 
good), he should be patient and accept the taqdir. If the taqdir is a favor that conforms to what he had set up and worked for, then he should be grateful to God and should praise for it. If he commits a sinful deed, he should ask God's forgiveness and repent. The slave's stand towards the Commands of God has two levels: (1) before execution: a determination to fulfill the command and to seek God's help for its execution; (2) after execution: Seeking God's forgiveness due to any shortcomings in the execution, and praising God for all of His favors: "So be patient (O Muhammad). Verily, God's promise is true, and seek forgiveness for your fault" (40:55) (quoted in As-Saleh 1995).

From the abovementioned statement, we can understand that man has to initiate his own action before and after his qadar takes place. This is the essential part of his power and ability that has been given by God - he is not a robot that has neither will nor power - he is after all free to choose his own action, but he must submit his action to God, for he is His creation his power is subject to God's Will and Power. His free will and initiative is the most important part of his action and this is actually the most distinctive different between man and other God's creatures. Therefore, according to As-Saleh, if man do not take any action: ". . to go and search for his provisions but instead waits for the al-qadar, does not comprehend the taqdir of God to His servants: 'So walk in the path thereof (on earth) and eat from His provisions'"' (76:15) (quoted in As-Saleh 1995). Also, if God had ordained to give a person a child, this means that He had intended for him a consummated marriage for the child does not come without a cause, as also other things in this world do not happen without a cause (As-Saleh 1995). Understanding in this light, a Muslim must act to create his qadar before it takes place - which definitely exists in the future time - for that is the only time he could make any difference for himself or his society.

In the Quran we read: "Oh ye who believe! Observe your duty to God. And let every soul look to that which it sent on before for the morrow" (59:18). Also, in other verse, we read: "Never say about anything, I shall do this tomorrow", without adding: "if God so wills." Should you forget, then call your Lord to mind and say: "I pray that my Lord will guide me even closer than this to what is right" (18:23-24). In commenting the verse, Sayyid Qutb views that the verse demonstrates God's prohibition upon making pre-judgment on future events for it is beyond human perception. Furthermore, he stresses that every human action is subject to God's will, hence he should avoid making any assertion about future but this does not imply a fatalistic outlook on life.

On the contrary, Sayyid Qutb asserts that the verse implies that every human should rely on God in his life but at the same time, work out with his plans in confidence for he is not alone in executing the plans. His submission to God's will shall neither overtake him during failure nor deceive him during success for he will resign for whatever God's will may determine (Sayyid Qutb 2004). In addition, Sayyid Qutb adds that the verse: "Should you forget, then call your Lord to mind" advises a Muslim to: ". . remember God and renew his reliance on Him. He should also hope to remain always conscious of God, turning to Him in all situations and all future actions, always saying: I pray that my Lord will guide me even closer to than this to what is right" (Sayyid Qutb 2004). Therefore, at the final stage, a Muslim's spirituality becomes elevated in every situation and endeavour. In this regard, Elmandjra stresses that the Quran call human being to make the best possible use of the present and to carefully and intelligently prepare for the future, in which the future means the rest of human life on the earth and the hereafter. It should also be noted, that the Quran advises against making presumptuous claims of prescience and foreknowledge, but it does recommend human being to make projections and work out different options in order to enhance their ability to cope with the requirements of the future and to improve their well-being.

Elmandjra's analysis on the Quranic convention of the word mustaqbal or mustaqbil, states that there is a clear distinction between al-ghayb, the hidden aspect of future which is 
within the realm of God and the term mustaqbil, which implies the anticipation of developments arising from what we do or fail to do today. Hence, he asserts that the common usage of the word mustaqbil to denote future is clearly not about prophecies but forecasts. Elmandjra believes that Islam is a vision of life on earth and also in the hereafter. It calls on man to seek command of his own fate and to adopt a dynamic approach in his political, economic, social and cultural initiatives. Consequently, this dynamic approach towards life and its qadar perceives change as an essential ingredient for a better future. In the Quran, we read: "Lo! God changeth not the condition of a folk until they (first) change that which is in their hearts" (Surah 13:11). Change, therefore, needs to be approached as a prerequisite to move forward, and it is the heart, the spiritual element of human intellect that needs to be changed first and foremost. Iqbal's analysis regarding the nature of pure time as an organic whole has given different perspective in departing time from its conventional and linear characteristic of the Western time as well as the classical Islamic discourse of time as discussed previously. A deeper analysis of our conscious experience, he says, revealed that pure time:

is not a string of separate, reversible instants; it is an organic whole in which the past is not left behind, but is moving along with, and operating in, the present. And the future is given to it not as lying before, yet to be transversed; it is given only in the sense that it is present in its nature as an open possibility. It is time regarded as an organic whole that the Quran describes as 'Taqdir' or the destiny - a word which has been so much misunderstood both in and outside the world of Islam. Destiny is time regarded as prior to the disclosure of its possibilities. It is time freed from the net of causal sequence - the diagrammatic character which the logical understanding imposes on it. In one word, it is time as self and not as thought and calculated (Iqbal 1999).

It is a dynamic conception of time which operates organically that gives the real sense of time - time as a whole and continuous process which never lasted in particular period -it actually 'lives' in past, present and future, and this is why qadar or in Iqbal's usage, taqdir, could not be regarded as a fix and unchangeable matter. It is in fact a continuous process. As Iqbal explains:

Time regarded as destiny forms the very essence of things. As the Quran says: 'God created all things and assigned to each its destiny'. The destiny of a thing then is not an unrelenting fate working from without like a task master; it is the inward reach of a thing, its realizable possibilities which lie within the depth of its nature, and serially actualize themselves without any feeling of external compulsion. Thus the organic wholeness of duration does not mean that full-fledged events are lying, as it were, in the womb of Reality, and drop one by one like the grains of sand from the hour-glass. If time is real, and not a mere repetition of homogeneous moments which make conscious experience a delusion, then every moment in the life of Reality is original, giving birth to what is absolutely novel and unforeseeable. 'Every day doth some new work employ Him', says the Quran. To exist in real time is not to be bound by the fetters of serial time, but to create it from moment to moment and to be absolutely free and original in creation (Iqbal 1999).

This dynamic concept of time also denotes the dynamic concept and application of qadar. It shows man open possibilities and opportunities in effecting his life in the future. However, this open possibilities and opportunities will never benefit man unless he has purpose in life. For Iqbal, life, though not teleological in the sense of being implemented according to a preconceived plan, is purposive activities. The concept of self too implies purposiveness. In this regard, Iqbal further explains that: 
Life is only a series of acts of attention, and an act of attention is inexplicable without reference to a purpose, conscious or unconscious. Even our acts of perception are determined by our immediate interests and purposes ... thus ends and purposes, whether they exist as conscious or subconscious tendencies, form the warp and woof of conscious experience. And the notion of purpose cannot be understood except in reference to the future. The past, no doubt, abides and operates in the present; but this operation of the past in the present is not the whole of consciousness. The element of purpose discloses a kind of forward look in consciousness. Purposes colour not only our present states of consciousness, but also reveal its future direction. In fact, they constitute the forward push of our life, and thus in a way anticipate and influence the states that are yet to be. To be determined by an end is to be determined by what ought to be.Thus past and future both operate in the present state of consciousness ... (Iqbal 1999).

By describing the significant role of purposive acts, Iqbal points out his organic conception of time which integrates the past with the future through the present within the perception of human consciousness and unconsciousness. In fact, it shows that human in actual, is fully engaged in creating his life the way he chose it within the time-frame that has been granted to him. Therefore man has the ability to influence his qadar through his purposive acts executed by his very own free will. His future is not fixed in a pre-conceived plan by God, for Iqbal believes that God grants freedom to human egos who are to share His creative activity. He admits that the emergence of egos endowed with the power of spontaneous and hence unforeseeable action is in a sense a limitation of the freedom of the all-inclusive Ego, but this limitation is not externally imposed. It is born of God's own creative freedom whereby He has chosen finite egos to be participators in His life, power, and freedom. Iqbal considers the prevalent idea of God's absolute omnipotence to be a misconception (Iqbal 1999). God's knowledge is not omniscience in the sense of an immediate awareness of the entire sweep of history - past, present and future - regarded as an order of specific events in an eternal everpresent 'now'. To him this suggests a closed universe, a fixed futurity, a predetermined, unalterable order of specific events, which, like a superior fate, has once and for all determined the direction of God's creative activity.

Iqbal's explanation on this is said to solve the problem of free will by denying God's foreknowledge, in which he conceives as sacrificing His freedom as conceded by the orthodox theology and neglected the true Quranic spirit. For Iqbal, Al-Ghazali's revolt against Greek intellectualism is a huge achievement in Islamic thought and philosophy, but his resort to Sufism demonstrated the failure in understanding the organic relationship between thought and intuition, and: ". . that thought must necessarily stimulate finitude and inconclusiveness because of its alliance with serial time" (Iqbal 1999).

The integrative conception of time within its organical relationship views time in its simultaneous consciousness between past, present and future, which, according to Iqbal, agrees with the dynamic spirit of the Quran. Within this integrative paradigm, the modern Islamic discourse on time attempts at disclosing the whole human conscious experience in human history. According to Imad al-Din Khalil, the Quranic interpretation of human history proceeds from the vision of God who: ". . . has a comprehensive knowledge of historical events in their three time elements: past, present, and future, and in their fourth dimension which often vanishes from human thought no matter how intelligent, incisive, and perceptive a person may be. This is the dimension that probes the depth of the human soul impinging on the nature of man, his intrinsic identity, and the dynamic movement of his inner being. It penetrates deeply into his intellectual, emotional, and psychic vibrations, and his antecedent will ... For it is the vision of the divine being 
which permeates all things with knowledge and has fashioned the historical event and placed it in its ordained place in the design of human and cosmic history" (Imad al-Din 1982).

Obviously, the fourth dimension of time which escaped Iqbal's explanation of human consciousness is regarded by Imad al-Din as the dynamic nature of man (fitrah). And, whereas Iqbal relates human consciousness with his purposive acts that works within the time-frame that is given by God as an open possibilities influencing the human qadar, Imad al-Din stresses the Quranic interpretation of history and time as being fashioned by the dynamic human nature incongruent with the determinist history of humanity through the work of general principles or laws (sunan or sunnatullah). These laws that governs both human and natural world, are the forces that influence human history in times. It is these laws that bind the human past, his present and future life, since the Quran views times are as a unified whole, in which past, present, and the future commingle in a common destiny and continuous living unity. The movement of history which encompasses creation, Imad al-Din further asserts, becomes one movement towards the Day of Judgment (Imad al-Din 1982). Therefore, the modern discourse on time is seen to be closer to the Quranic interpretation of human history, without delving into the depth of the cosmological and ontological planes which, in the context of contemporary debates, can be regarded as futile and vain.

Al-Qardawi avers that futures thinking has its own ground and significance in Islam, as vastly shown in the Quran and hadith and the Sunnah of the Prophets. His firm assertion on the centrality of futures thinking in Islam attempts to open the mind of the Muslim Ummah that has long trapped in their nostalgic and apologetic state and urges them to realize contemporary realities particularly the advancement of Western knowledge and their economic achievement. $\mathrm{He}$ also asserts that the dynamic understanding of the Islamic teachings as propagated by the Prophet has enabled the Sahabah to build a remarkable human civilization compatible with the needs and demands of their age within fifty years. This fresh and correct understanding of the true message of Islam as has been developed throughout twenty three years of living and witnessing the words and pious life of the Prophet has given them extraordinary qualities to become the source of inspiration for the later Muslims generations. However, he argues that the renunciation of dynamic interpretation and implementation of the Islamic ideals among contemporary Muslims particularly relating to the question of future has caused degeneration in Muslim societies all over the world. He says:

There are Muslims who do not have the opportunity to study and learn about Islam thoroughly and yet assume that this religion did not accept futures theories which present the study of future possibilities, ways and strategies to deal with them efficiently. They also presume that religion is only about organizing people in the past and their old heritage which regarded as 'sacred' and 'pure' from any fault and mistakes. This kind of belief has imprisoned them in their own 'golden cage' of old heritage and consequently prevented them from any movement and change. According to them, the question of the future must be fully submitted to God for it is unknown to human beings and they have no power over it. Human being could not do anything to accept or reject future upcoming events, but only submitting their fate to al-qada' and al-qadar (taqdir), and they have no capabilities to reject or choose (Al-Qardawi 1996).

We agree that the degeneration of the Muslim Ummah is mainly caused by reductionist attitude in understanding the core and essence of the Islamic teachings. This narrow- and rigidminded thinking has prevented the Muslim Ummah from perceiving the principal and contextual values in the vast Islamic corpus of knowledge and history. Hence, it has limited Islam to a set of ritual practice and eventually lost its significant and magnificent contributions which have produced the most excellent thoughts and civilizations in human history. The 
phenomenon of reductionist thinking, narrow-mindedness and blind acceptance (taqlid) has finally resulted in rigidity and stagnation in ideas and actions. The issues of Muslims predicament have been widely debated by many Muslims scholars. In this regard Al-Qardawi (1996) urges the Muslim Ummah to choose the middle way and learn from the past to live in the present and without fail to prepare themselves to face the upcoming future and to shrink neither in the past nor in the future stream extremely for both attitudes do not bring any benefit to them as Islam advocates the notion of equilibrium in all aspects of human endeavour.

The Islamic view on future is therefore cannot be understood separately from the concept of fitrah (human nature) and qadar (predestination) as it both relates three main components of human actions, that are human himself as the agent, human's free will as human potential to effect actions resulted from the manifestation of qadar and finally the taking place of the actions within time, that is the future time (as understood as a continuous present). Despite the zealous appeal of Islamic resurgence especially among the younger Muslim generations, the development of new intellectual discourse as an alternative approach to resolve Muslims' problems in a more directive way within the postmodern context must be taken seriously by the Muslim scholars and intellectual. Apparently, the Muslim scholars have a huge and challenging responsibility for this means that they have to work based on the foundation and paradigm guided by the early Muslim generations through the renewal process of the aql (thought) through ijtihad and the human action (jihad).

\section{References}

Abdul Rahman ibn Saleh al-Mahmud cited in As-Saleh, Saleh S. 1995. Fate in Islam: The Salaf's guide to the understanding of al-Qada' wa al-Qadar. Madinah: Dar al-Bukhari.

Abdullah Yusuf Ali. 1992. The Meaning of the Holy Quran. Maryland: Amana Corporation.

al-Anani, Hasan. 1990. Freedom and responsibility in Quranic perspective. (Transl.). M.S Kayani). Indianapolis: American Trust Publication.

Ba`albaki, Ruhi. 1995. Al-Mawrid. Beirut: Dar al-'Ilm al-Malayin.

Elmandjra, Mahdi. 1990. The Future of the Islamic World. A paper presented in the Symposium on The Future of the Islamic World. Algiers. 4-7th May.

Imad al-Din Khalil. 1975. The Quranic interpretation of history. Selected from al-Tafsir al-Islami li al-Tarikh. In, Yvonne Yazbeck Haddad. 1982. Contemporary Islam and the Challenge of History. Albany: State University of New York Press.

Iqbal, Muhammad. 1999. The Reconstruction of Religious Thought in Islam. Lahore: SH Muhammad Ashraf Publishers.

Moazzam Anwar. 1984. Jamal al-Din al-Afghani: A Muslim intellectual. New Delhi: Concept Publishing Company.

Nasr. 1996. in Oliver Leaman (ed.). History of Islamic Philosophy. London: Routledge.

al-Qardawi. 1996. Islamic Culture between tradition and modernity. (Transl). Ahmad Nuryadi Asmawi. Selangor: Thinker's Library.

1996a. Al-Ummah al-Islamiyyah: Haqiqah la wahm (An Islamic Ummah: Reality not fantasy). (Trans.). Ahmad Nuryadi Asmawi. Selangor: Thinker's Library.

Qutb, Sayyid. 2004. Fi Zilal al-Quran. Vol. X. (Transl) Adil Salahi. Leicestershire: The Islamic Foundation.

As-Saleh, Saleh S. 1995. Fate in Islam: The Salaf's guide to the understanding of al-Qada' wa alQadar. Madinah: Dar al-Bukhari.

Watt, Montgomery W. 1985. Islamic Philosophy and Theology: An Extended survey. Edinburgh: Edinburgh University Press. 1994. Islamic Creeds: A Selection. Edinburgh: Edinburgh University Press. 